\title{
THE EFFECT OF INCENTIVES ON SATISFACTION OF SPECIALISTS AT IMELDA GENERAL HOSPITAL, MEDAN, NORTH SUMATERA
}

\author{
Lie Novita Sadeli, Ida Yustina, Destanul Aulia
}

Masters Program in Public Health, Faculty of Public Health, Universitas Sumatera Utara

\begin{abstract}
Background: Doctors have an important role in hospital, where almost all of the patients who come to hospital are looking for a doctor to be treated. Incentives were given to the doctor as a token of appreciation to doctor, also to increase specialist work satisfaction. This study aimed to determine the effect of incentives which was given by the hospital on specialist's work satisfaction at Imelda Hospital, Medan.

Subject and Method: This was a cross sectional study carried out at Imelda Hospital, Medan. A sample of 34 specialists were selected for this study by exhaustive sampling from all of the specialists who worked at Imelda Hospital Medan. The dependent variable was work satisfaction. The independent variable was incentive. The data were collected by questionnaire and analyzed by a linear regression model.

Results: Work satisfaction was associated with the amount of incentive and the punctuality to receive incentive.

Conclusions: Work satisfaction of specialist is associated with incentive.

Keywords: incentive, work satisfaction, specialist

\section{Correspondence:}

Lie Novita Sadeli. Masters Program in Public Health, Faculty of Public Health, Universitas Sumatera Utara, Jl. Universitas No. 21, Kampus USU, Medan 20115, North Sumatera. E-mail: qian_siz@yahoo.com. Mobile: o81361631199
\end{abstract}

